\title{
UPAYA MENINGKATKAN KEMAMPUAN MENULIS MELALUI LEARNING LOGS DAN CONFERENCING
}

Dwi Sulistyorini ${ }^{1)}$

Program Studi Teknika Akademi Pelayaran Niaga Indonesia rini@akpelni.ac.id

\section{ABSTRAK}

Berdasarkan kurikulum 2009, seluruh mahasiwa Program Studi Pendidikan Bahasa Inggris wajb menempuh mata kuliah Writing 4. Mata kuliah ini bertujuan untuk memberikan pengalaman belajar dalam menulis artikel untuk seminar berbahasa Inggris dan dalam membuat tulisan ilmiah tentang berbagai jenis topic dalam bentuk esai. Mata kuliah ini melibatkan kegiatan di dalam dan di luar kelas.

Permasalahan yang terkait dengan mahasiswa yang ada dikelas Writing 4 khususnya kelas $4 B$ cukup beragam, yang semua dikategorisasi menjadi permasalahan dalam kelaswriting 4 yang bersumber dari mahasiswa dan dosen.

Masalah yang akan dicoba diatasi melalui penelitian ini adalah kemampuan menulis teks ilmiah bahasa Inggris yang meliputi rendahnya kemampuan dalam mengembangkan esai (pendahuluan, isi dan kesimpulan, rendahnya kemampuan sitasi (citation) dan referensi (referencing), dan rendahnya kemampuan tata bahasa.

\section{A. Tujuan Penelitian :}

Tujuan penelitian ini adalah untuk meningkatkan keterampilan menulis ilmiah mahasiswa prodi Pendidikan Bahasa Inggris Semester 4 dengan menggunakan Learning Log dan Writing Conference.

Permasalahan di dalam penelitian ini dirumuskan dalam pertanyaan berikut:

"Bagaimana Learning Log dan Writing Conference dapat digunakan untuk meningkatkan kemampuan menulis teks ilmiah bahasa Inggris mahasiswa Prodi pendidikan Bahasa 
Inggris semester 4?"

\section{B. Kajian Pustaka}

1. Keterampilan Menulis Ilmiah (Academic Writing)

Menulis merupakan salah satu diantara empat keterampilan utama dalam pembelajaran Bahasa Inggris yang termasuk kategori productive skill yakni kemampuan yang menitikberatkan pada produksi bahasa. Secara sederhana Writing ini bisa diartikan sebagai cara penyampaian pesan (sesuatu yang akan dikatakan) melalui kode atau tanda yang ditulis di atas kertas (Spratt dkk., 2005: 26). Untuk dapat menghasilkan sebuah karya berbentuk tulisan yang baik, diperlukan kemampuan untuk menyampaikan informasi atau pesan secara efektif dengan menggunakan kalimat-kalimat yang bermakna (Spratt dkk., 2005: 26).Menurut mereka (2005: 27), langkah-langkah tersebut meliputi: brainstorming, making notes, planning, writing a draft, editing, producing another draft dan proof reading.

Selama ini ada beberapa masalah yang mempengaruhi proses pembelajaran menuliskhususnya bagi mahasiswa Pendidikan Bahasa Inggris yang merupakan calon guru BahasaInggris. Perbedaan budaya menjadi salah satu unsur pencetus masalah. Disebutkan oleh Morgan(2005:4) yang melalukan penelitian kepada mahasiswa internasional, penduduk asli Australia dan penuutur asli bahasa Inggris di Australia. Menurutnya bagi penutur asli bahasa Inggris semua persyaratan teks ilmiah demikian jelas dan terang namun tidak demikian bagi mahasiswa internasional (di Australia) dan penduduk asli Australia (aborigin). Dua kelompok terakhir ini mengalami kesulitan dalam memenuhi prasyarat menulis teks akademik. Budaya dan tradisi berfikir yang berbedaberperan besar dalam hal ini. Cara manusia dalam mengungkapkan makna memiliki perbedaan, misalnya bangsa-bangsa di Asia cenderung 
kurang straightforward dan to the point di banding bangsa Eropa. Walau begitu, seiring dengannya kemajuan pendidikan dan informasi bisa jadi stigma seperti ini sudah tidak relevan lagi. Menurut genre-based approach, menulis merupakan proses berfikir kritis dalam memproduksi teks. Kegiatan ini bukan semata-mata proses menghasilkan teks yang melibatkan fitur-fitur kebahasaan tetapi juga melibatkan konteks dan latar belakang budaya dan sosial dimana teks sebagai discourse (wacana) serta konvensi dimana teks tersebut dihasilkan dalam discourse community Tertentu (Zeng in Gao, 2007). Sehingga dalam menulis mahasiswa harus memiliki kompetensi tentang konteks dimana teks tersebut terjadi, kompetensi tentang latar belakang sosial dan budaya, serta kompetensi tentang fiturfitur kebahasaan. Faktor sikap dan kepribadian mahasiswa memberikan peranan dalam percepatan pencapaian kemampuan menulis. Liu (2007) melaporkan bahwa responden yang ditelitinya menunjukan sikap positif terhadap pembelajaran bahasa Inggris dan sangat termotivasi untuk belajar bahasa Inggris. Motivasi dan sikap tersebut berkorelasi positif terhadap kemampuan bahasa Inggris mereka. Sementara itu, Jaheen and Idrees (2012: 44) menemukan fakta bahwa kemampuan menulis berkorelasi sifnifikan dengan kemampuan bahasa Inggris secara keseluruhan. Namun, mereka menemukan bahwa tidak ada hubungan signifikan antara sikap (attitude) calon guru bahasa Inggris terkait motivasi dan keinginan belajar bahasa Inggris dengan kemampuan menulis. Ini berarti mereka yang sangat termotivasi dan tertarik untuk belajar bahasa Inggris tidak serta merta mampu menulis dengan baik. Fenomena ini memang sering terjadi. Mahasiswa menujukan perhatian dan semangat yang tinggi saat pembelajaran namun hal itu tidak lantas membuat mereka mampu menghasilkan karya yang mencapai standar tententu. Untuk mahasiswa seperti ini diperlukan perlakuan tertentu sesuai dengan jenis dan 
tingkat permasalahan yang dialami karena ternyata semangat dan motivasi saja tidak cukup kuat untuk mengantarkan seseorang mencapai profisiensi menulis.Selanjutnya, suasana pembelajaran termasuk pilihan teknik serta prilaku pengajar/ dosen juga mempengaruhi pembelajaran menulis ini. Dalam kelas menulis peran seorang dosen dalam memberikan scaffolding atau bantuan dalam bentuk aktivitas serta umpan balik sangat diperlukan. Beberapa mahasiswa memiliki kepribadian yang dibutuhkan bagi seorang pembelajar bahasa misalnya open-minded (terbuka terhadap hal baru) dan berani mengambil resiko. Tidak semua orang bisa bersikap positif terhadap feedback negatif yang diterimanya. Beberapa diantaranya merasa kecewa, malu, atau perasaan negatif lain saat mendapat penilain yang tidak sesuai harapan. Oleh karena itu seorang pendidik dituntut untuk berimbang dalam memberikan umpan balik dalam menulis dan berorientasi pada perbaikan, buan sekedar memberitahu kesalahan. Menurut Maden (1988) yang dikutip Mourtaga beberapa hasil riset mengungkapkan sekitar 50 persen siswa mengalami kegagalan karena karena tidak terpenuhinya kebutuhan manusiawi mereka, seperti kasih sayang, kemerdekaan, dan kekuatan, sehingga mereka tidak berusaha keras. Pengajar writing, menurut Mourtaga, bukan pencari kesalahan implementasi learning logs dan writing conference dalam meningkatkan kemampuan menulisPortofolio digunakan untuk melihat kemajuan hasil belajar mahasiswa. Kamera dan videodigunakan untuk mendokumentasikan data dalam bentuk gambar dan video.Data yang dikumpulkan dalam penelitian ini adalah data kuantitatif . Data kualitatif akan dianalisis dengan langkah:1) kategorisasi, yaitu memilih dan memilah informasi dengan menggunakan inductive coding, 2) melakukan initial coding, yaitu menghubungkan tematema yang muncul dari data terseleksi dan relevansinya dengan pertanyaan penelitian,3)menajamkanfokus dengan 
melakukan wawancara terstruktur dan mendalam ,4) memilih dan memilah data tambahan dengan membaca hasil wawancara mendalam dengan teliti dan seksama kemudian mengelompokan data tambahan ke dalam kategori yang sudah ada atau membuat kategori baru,5)menarik kesimpulan dari penajaman fokus penelitian yang dilakukan berulang. Penelitian ini menggunakan prosedur penelitian tindakan kelas yang ditawarkan oleh Kemmis dan McTaggart (1988) dalam Burns (2010) yaitu : perencanaan (Plan), tindakan dan pengamatan(Do and Observe) dan dan refleksi (Reflect). Untuk menjamin validitas data peneliti akan menggunakan :democratic validity, process validity, dialogic validity, outcome validitydan catalytic validity (Burns, 1999: 161). Reliabilitas data dilakukan dengan triangulasi yang meliputitime triangulation, space triangulation, investigator triangulation dantheoretical triangulation

D. Hasil

Dari keseluruhan siklus, secara umum terlihat peningkatan kemampuan mahasiswa dalam menulis teks ilmiah. Mahasiswa merasa mendapat banyak wawasan dari perkuliahan ini. Berikut hasil wawancara dengan 2 mahasiswa.

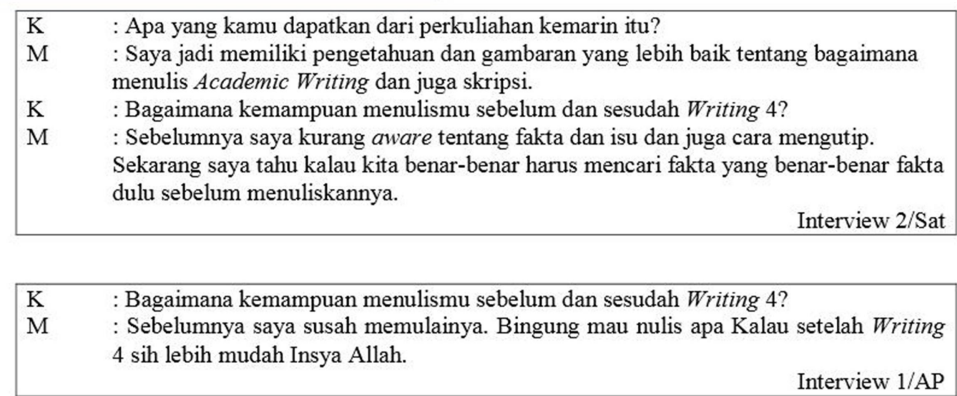

Hal spesifik lain terkait peningkatan kemampuan menulis dijabarkan berdasarkan indikator berikut:

a. Peningkatan dalam kemampuan konten dan tata bahasa 
Dibanding dengan karya mereka di awal dan tengah perkuliahan, tingkat kesalahan tata bahasa, termasuk tanda baca dan ejaan, sudah berkurang walau bukan berarti hilang samasudah berkurang walau bukan berarti hilang samasekali. Berikut hasil wawancara dengan salah satu mahasiswa yang merasakan peningkatan dari aspek ini.

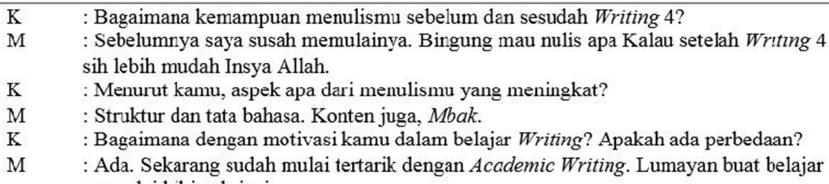

Interview/AP

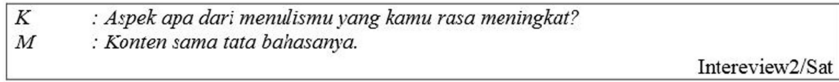

Dalam perkuliahan writing, tidak cukup waktu untuk mengulas secara rinci teori grammarBuntuk membantu mahasiswa memperbaiki kesalahan. Oleh karena itu dosen berusaha untukBmembuat mereka belajar secara mandiri terutama tentang tata bahasa dan struktur. Berikut catatan di learning log seorang mahasiswa. 


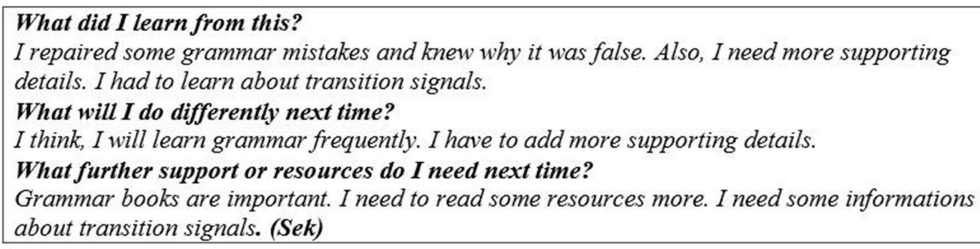

b. Peningkatan kesadaran dan kemampuan menata argument di bagian pendahuluan,tubuh dan kesimpulan Dibanding dengan karya sebelumnya, karya dalam tugas akhir dan UAS lebih baik. Mahasiswa mampu mengaitkan ide yang ada di bagian introduction dengan bagian body dan conclusion. Mahasiswa menyadaripentinya koherensi dalam tulisan mereka tremasuk menata tubuh paragraph sesuai dengan thesis statement. Berikut tulisan mahasiswa dilearning log.

\footnotetext{
What did I learn from this?

I learned that I have to be more careful in determining the grammar that I use. I also have to develop my body paragraphs well based on the thesis statement and give more details related to the main idea. And the most important thing is that I have to make my essay coherent.

What will I do differently next time?

First, I will make the thesis statement more specific so that I will not get some difficulties in making the body paragraph, because the body paragraphs are based on the thesis statement. Second, I will be more careful in deciding who are my readers, so my essay will be more understandable. (Rd)
} 
Mahasiswa juga merasakan bahwa selama perkuliahan mereka mulai merasakan peningkatan kemampuan dari segi cara berfikirdan menata argument. Berikut hasil wawancara dengan mahasiswa yang mengaku mendapat ilmu baru tentang cara menstukturisasi karangan. Mahasiswa ini juga merasa kemampuannya berembang dan juga cara berfikirannya.

\begin{tabular}{|c|c|}
\hline $\mathrm{K}$ & : Apa yang kamu dapat dari perkuliahan Writing 4 kemarin? \\
\hline M & $\begin{array}{l}\text { : Yang paling pokok sih kita dapat cara berpikir yang lebih logis. Logika nulisnya } \\
\text { pokoknya dapet banget, Mbak. Yang tadinya saya kurang terstruktur dalam menulis, } \\
\text { kini dapat pengetahuan baru tentang cara meng-quote dan cari reference juga. }\end{array}$ \\
\hline & \\
\hline $\mathrm{K}$ & : Kalau menurut kamu sendiri, kelebihan dari metode kemarin apa? \\
\hline M & $\begin{array}{l}\text { Di Writing } 4 \text {, feedback nya lebih gamblang. Jadi gak Cuma Grammar aja yang dilihat } \\
\text { tapi proses dari awal kita menulis juga direview. Saya sih ngerasanya tulisan saya jadi } \\
\text { lebih berkembang, pun begitu dengan cara berfikirnya. }\end{array}$ \\
\hline $\mathrm{K}$ & : Kalau kemampuan menulis esai mu sekarang bagaimana? \\
\hline M & : Meningkat. Disini ilmu yang didapat banyak banget soalnya. (Interview1/AP) \\
\hline
\end{tabular}

\begin{tabular}{|ll|}
\hline $\mathrm{K}$ & : Apa yang kamu pelajari dari aspek menulis dan non menulis? \\
$\mathrm{M}$ & : Banyak, $M$ bak. Contohnya ya tentang cara berfikir reflektif, kritis, dan bagaimana \\
& kita mengaplikasikan cara meng-quote dan menghindari plagiasi. Kalau dari aspek \\
& non menulis, kita lebih tahu cara mengungkapkan ide. Cari permasalahannya harus \\
& jelas agar nanti logika tulisannya ada. Yang paling saya ingat sih $B u$ Lusi pernah \\
& bilang kalau bisa jangan sampai ada celah untuk statement kita terpatahkan.
\end{tabular}
Interview 1/AP

c. Peningkatan wawasan tentang plagiasi dan kemampuan cara menghindarinya

Kutipan dan referensi adalah salah satu cirri kaya akademik ilmiah. Melalui perkuliana ini mahasiswa merasakan dan menyadari arti penting keotentikan ide dan kejujuran dalam mnegutip pendapat orang lain. Beberapa mahasiswa sebelumnya tidak mengetahui apa sebenarnya plagiasi dan dampaknya. Melalui mata kuliah ini mereka mendapat informasi tentang cara menghindari plagiasi dengan mempelajari tentangcitation, referencingjuga paraphrasing. Berikut data terkait hal tersebut. 
$\mathrm{K} \quad$ : Apa yang kamu pelajari baik dari aspek menulis dan non menulis?

M : Yang paling ngena sih saya jadi lebih tahu cara mengutip dan membuat kalimat sehingga tulisan saya menjadi lebih akademik. Independent learning nya juga lumayan. Terus sekarang juga jadi semakin aware sama citation.

Interview $1 / \mathrm{Ap}$

$\mathrm{K}$ : Oke, yang terakhir ya. Apa manfaatnya bagi kemampuan menulis dan non menulismu?

M : Yang paling penting sih kita jadi bisa belajar menghindari plagiarisasi. Bisa belajar bikin skripsi juga jadinya.

Interview $2 /$ Sat

2. Pendapat mahasiswa tentang learning log

Penelitian ini menunjukan bahwa learning log diapresiasi positif oleh mahasisw a. Learning

log dilengkapai dengan beberapa pertanyaan yang harus direspon oleh mahasiwa. Selain membantu mahasiswa dalam menuliskan aspek-aspek yang mereka dapat dari perkuliaan, learning log juga melatih mahasiswa berfikir reflektif dan kritis. Mereka dilatih untuk peka dengan apa yang mereka alami selama perkuliahan juga merencanakan perbaikan untuk dirinya. Berikut pendapat mahasiwa tentanglearning log:

K :.....Bagaimana pendapat kamu mengenai pengalaman belajar Writing 4 kemarin?
Yang learning log sama writing conference.
: Menurut saya, kalau yang learning log itu bagus karena kita bisa mendapatkan
review balik terhadap tulisan kita. Yang oke itu adalah ketika kita tahu apa yang kita
dapatkan kedepannya.
Interview I/AP

K $\quad$ : .... Selama kuliah Writing 4 kemarin apa pendapat kamu? Khususnya tentang learning log dan writing conference.

M : Bagus, Mbak. Semua mahasiswa mendapatkan feedback masing-masing. Learning $\log$ nya juga atraktif.

Interview $2 /$ Sat

$\mathrm{K} \quad$ : Menurut kamu sendiri peer review, direct feedback dan conference nya bagaimana?

2. Pendapat tentang conferencing

Conferencing dalam penelitian ini melibatkan tahapan peer review, presentasi, serta umpan balik dari dosen. Kegiatan ini diapresiasi positif oleh mahasiswa. Berikut pendapat 
mahasiswa tentang kegiatan ini:

\begin{tabular}{|lr|}
\hline M : Peer review nya bagus. Jadi sebelum dikonferensikan diteliti dulu. Direct feedback \\
nya juga sangat membantu karena fokus pada permasalahan yang didapat tiap \\
mahasiawanya. Conference nya juga oke sih, Mbak.
\end{tabular}

Mahasiswa merasa senang dengan adanya feedback baik dari sesama teman maupun dosen. Mahasiswa lebih merasa yakin saat mendapat feedback dari dosen. Mahasiswa juga berfikir bahwa feedback disertai solusi dan saran lebih membantu mereka dalam mengembangkan kemampuan menulis. Berikut data terkait hal itu:

\begin{tabular}{|ll|}
\hline $\mathrm{K}$ & : Kalau tentang feedback dari teman dan dosen bagaimana? \\
$\mathrm{M}$ & : Kalau sama teman itu terkadang harus berdebat dulu karena masing-masing dari \\
kita kekenth sama pendapatnya. Kalaı dari dosen sih lebih kayak dikasih \\
pencerahan, Mbak. Per poin yang kurang benar dijabarkan jadinya lebih termotivasi. \\
\end{tabular}

\begin{tabular}{|c|c|}
\hline $\mathrm{K}$ & : Kalau menurut kamu sendiri, kelebihan dari metode kemarin apa? \\
\hline M & $\begin{array}{l}\text { : Di Writing } 4 \text {, feedback nya lebih gamblang. Jadi gak Cuma Grammar aja yang } \\
\text { dilihat tapi proses dari awal kita menulis juga direview. Saya sih ngerasanya tulisan } \\
\text { saya jadi lebih berkembang, pun begitu dengan cara berfikirnya. }\end{array}$ \\
\hline $\mathrm{K}$ & : Kalau kemampıan menulis esai mu sekarang bagaimana? \\
\hline $\mathrm{M}$ & : Meningkat. Disini ilmu yang didapat banyak banget soalnya. \\
\hline $\mathrm{K}$ & : Bagaimana menurutmu tentang peer review, direct feedback dan conference nya? \\
\hline M & $\begin{array}{l}\text { Peer review sih lumayan bagus mbak, hanya saja terkadang antara kita sama } \\
\text { reviewernya terkadang bingung apakah hal yang kita tulis itu benar atau gak. Ya } \\
\text { maklum lah mbak, kan masih sama-sama mahasiswa. Kemudian kalau direct } \\
\text { feedback nya menurut saya benar-benar membantu karena disini apa yang kurang } \\
\text { benar ya diberi jalan keluar tentang bagaimana cara merevisinya. Nah kalau } \\
\text { conference nya sendiri bisa membukakan jalan kita untuk mencari solusi. Karena }\end{array}$ \\
\hline $\mathrm{K}$ & $\begin{array}{l}\text { kan disini digabung antara pendapat tcman sama dosen. } \\
\text { : Apa bedanya feedback dari teman dan dosen? }\end{array}$ \\
\hline M & $\begin{array}{l}\text { Kalau dari teman sih buat sharing aja, Mhak. Kalau dari dosen sendiri, kesalahan } \\
\text { kita benar-benar diperbaiki. Lebih terpercaya pokoknya. }\end{array}$ \\
\hline
\end{tabular}

Interview $1 / \mathrm{AP}$

Writing conferences juga meningkatkan higher-order and critical thinking skills dan keterampilan belajar karena dengannya tersedia lingkungan sosial bagi ahli untuk berbagi dan menolong penulis baru supaya menjadi penulis independen (Flynn \& King, 1993). Writing conferences 
yang efektif meliputi diskusi yang bisa diprediksi dan fokus antara pengajar dan pembelajar, sehingga pembelajar bisa menghasilkan ide mereka sediri juga solusi terhadap permasalahan penulisan yang mereka hadapi. Dari interview terlihat mahasiswa merasa kegiatan ini membuka jalan untuk mereka mendapatkan solusi.

Penelitian ini bertujuan untuk menjawab pertanyaan "Bagaimana Learning Log dan Writing Conference dapat digunakan untuk meningkatkan kemampuan menulis teks ilmiah bahasa Inggris mahasiswa Prodi pendidikan Bahasa Inggris semester 4?" Dari 3 siklus, bisa disimpulkan bahwa learning $\log$ and conferencing dapat membantu meningkatkan kemampuan menulis teks ilmiah berbahasa Inggris (esai) mahasiswa. Penggunaan learning log dan conferencing mendapat tanggapan positif dari mahasiswa dan mahasiswa mendapat manfaat dari kedua jenis kegiatan ini khususnya dalam membantu proses pembelajaran menulis esai ilmiah. Dengan conferencing mahasiswa bisa mengetahui dan mendapat feedback secara langsung dan gamblang tentang kelebihan dan kekurangan dari tulisan yang mereka buat dari teman dan dosen, bertanya dan menjawab pertanyaan secara langsung, dan memberi komentar atau saran. Metode ini juga memungkinkan mereka untuk mengklarifikasi dan meminta penjelasan lebih lanjut.

Conferencing membantu siswa belajar dari kesalahan teman, melatih keberanian serta rasa percaya diri mahasiswa. Sementara itu Learning log membantu mahasiswa membiasakan diri untuk mengekspresikan diri. Melalui learning log dosen bisa memantau aspek mana yang mahasiswa sudah fahami dan mana yang belum. Selain itu, learning log dan conferencing 
membantu mahasiswa berfikir reflektif, kritis dan analitik. Dari penelitian ini juga terungkap peranan penting feedback dari dosen.

\section{REFERENSI}

Baykraktara, A. (2012) Teaching writing through teacherstudent writing coferences. Procedia - Social and Behavioral Science $51 \quad$ (2012) 709 - 713. http://www.nara-edu.ac.jp/CERT/bulletin2006/b2006H05.pdf

Bostoc, S. (2000). Student pear assessment. Retrieved on 12 February 2013 http://www.reading.ac.uk/web/FILES/engageinassessm ent/Student_peer_assessment_Sthepen_Bostock.pdf

Burns, A. (2010) Doing Action Research in English Language Teaching. NY : Rutledge.

Jahin, Jamal Hamed and Idrees, Muhammad Wafa (2012). EFL Major Student Teachers' Writing Proficiency and Attitudes Towards Learning English Umm Al Quro University Journal of Educational \& Psycologis Sciences Vol 4-No.1 - January retrieved from http://uqu.edu.sa/files2/tiny mce/plugins/filemanager/f iles/4280213/TR4-1-10.pdf

Kavaliauskiene, G. (2003) Two Activities for Fostering Autonomous Learning. The Internet TESL Journal, Vol. IX, No. 7 July

Lv. Fenghua and Chen, Hongxin (2010). A Study of Metacognitive-Strategies-Based Writing Instruction for Vocational College Students English language Teaching. Vol 3 No 3 . Retrieved in 
http://www.cosenet.org/journal/index.php/elt/article/vi ew/7224

Mourtaga, Kamal R. (2010). Poor Writing in English. A case of the Palestinian EFL learners in Gaza Strip 